\title{
OSZTÁLY, ÁLLAM ÉS FÜGGŐSÉG AZ EURÓPAI FÉLPERIFÉRIÁN
}

\author{
Bozóki András
}

(CEU)

A recenzió beérkezett: 2020. április 20. - véglegesítve: 2020. április 21.

(Scheiring Gábor: Egy demokrácia halála: Az autoriter kapitalizmus és a felhalmozó állam felemelkedése Magyarországon. Budapest, Napvilág Kiadó, 2019.)

Scheiring Gábor rendkívül gondolatgazdag, számos új nézőpontot felvető, provokatív könyvet írt a magyar demokrácia elhalálozásáról. Ritkán olvasni magyarul ennyire átgondolt, igényes, jól strukturált munkát, amelyben az elméleti és empirikus részek egymásra épülve erősítik az írás fő állításait. A szerző az Orbán-rezsimet - egyezően a hazai és nemzetközi politikatudomány domináns álláspontjával - versengő vagy választásos önkényuralmi rendszernek tekinti, és ebből következően a hibrid rezsimek körében helyezi el (vö. LevitskyWay, 2010; Schedler, 2005; Schedler, 2015.). De ez a könyv kevésbé szól a már előrehaladott állapotban lévő Orbán-rezsim természetéről (ehhez lásd például Scheiring-Szombati, 2019) mint inkább kialakulásának okairól.

A szerző a rendszerváltással létrejött törékeny magyar demokrácia történelmi kudarcának elsődleges okát a Kelet-Európában 1989 után dominánssá vált piaci fundamentalizmusban (vö. Soros, 1998) látja. Ennek elveit - dióhéjban a privatizáció, a dereguláció, a sokkterápia, a pénzügyi és kereskedelmi liberalizáció, a makrogazdasági stabilizáció és a piaci társadalom fogalmait - a magyar pártok elfogadták, így a középosztály alatti választói csoportok az 1990-es években nem találtak maguknak olyan politikai alternatívát, amely a szabadság mellett az egyenlőség elvét is hitelesen képviselte volna. Végül ezek a választók, türelmüket vesztve a „nemzet” kirekesztően értelmezett fogalmával operáló jobboldal és a szélsőjobboldali erők mellé sorakoztak fel. Scheiring kimutatja, hogy jelentős választói csoportoknál a változás lényegében abban állt, hogy az „osztály” fogalmát behelyettesítették a "nemzet” fogalmával, anélkül, hogy kezdetben tartalmilag változtattak volna alapvető beállítódásukon. A munkások, akik a kétezres évek elején még nem voltak fogékonyak az etnicista ideológiára (vö. Szalai Erzsébet, 2004), az évtized végére már többnyire abból indultak ki. A 2010-es politikai fordulat véget vetett a liberális demokrácia korszakának és a választók szabad utat engedtek egy (kezdetben 
majoritárius demokratának nevezett) illiberális, versengő önkényuralmi rendszer kibontakozásának.

Mivel Scheiring az 1990-2010 közötti korszakot hol demokráciának, hol pedig „„szimulált demokráciának” nevezi, nem mindig világos, hogy pontosan mire gondol. Az én értelmezésemben a szerző elitvezérelt, intézménycentrikus demokráciát ír le, amely az évek során is féloldalas maradt, mert nem erősödött meg az aktív társadalmi részvétel. Ennélfogva a demokrácia fogalmát sokan csak a többpártrendszerrel azonosították. E demokratikus deficithez képest azonban a szimuláció fogalma szándékosságot tételez fel a politikai aktorok részérôl, amit túlzás lenne a fenti húsz év egészére kiterjeszteni. Benyomásom szerint itt inkább arról lehet szó, hogy a kapitalizmus és a demokrácia együttes megjelenése súlyos ellentmondásokkal terhelt folyamat volt. Abból a tényből, hogy a demokráciák csak a kapitalista rendszerekben maradtak életben, még nem következik, hogy az újonnan létrejött kapitalizmus automatikusan demokráciához vezet. Az sem biztos, hogy a születőben lévő piacgazdaság automatikusan konszolidálja a történeti előzmények nélkül, nemzetközi dominóhatásra létrejött, félperifériás demokráciát.

A szerző által „,szimulált demokráciának" nevezett korszak inkább a 2010tôl kezdődő periódusra illik, amikor a rezsim - a kormányfo által „pávatáncként" leírt formában - a hivatalos politika rangjára emelte a kettős beszédet (az Orbán-rezsimről lásd Magyar-Vásárhelyi, 2017; Kovács-Trencsényi, 2020). Az időszak meghatározó pillanatai közé tartozott az egyoldalú alkotmányozás (2011), az alaptörvény negyedik kiegészítése, amely szétzilálta a jogállamiságot (2013), a szabad, de nem tiszta választások lebonyolítása és az „illiberális demokrácia" meghirdetése (2014). Ebbe a sorba illeszkedett a menekülthullám által jelentett veszélyek felnagyítása és propagandisztikus átértelmezése (2015), valamint az hatalmon lévő párt céljainak szolgálatába állított népszavazás (2016). Mivel az illiberális demokrácia fogalma - félrevezető elnevezése ellenére - nem demokrácia, hanem hibrid rezsim (vö. Bozóki-Hegedűs, 2018a), a kormányfő végül így deklarálta szakítását a rendszerváltás után fennállt nyugatias, demokratikus rendszerrel. A hibrid rezsim tipikus kommunikációs stratégiája a kettős beszéd, amely a hatalmon lévő politikai vezetők hazai és nemzetközi politikájában egyaránt megjelent. A Fidesz 2018-as, „félig szabad” választásokon aratott győzelme után a pávatáncra egyre kevésbé volt szükség, habár a választásos autokrácia egészen a 2020-as felhatalmazási törvény elfogadásáig fennmaradt (Scheppele, 2020).

Az Orbán-rezsim létrejöttének fő társadalmi oka Scheiring szerint a munkásosztály és a nemzeti tôkésosztály párhuzamos lázadása volt a neoliberális versenyállam teremtette növekvő egyenlőtlenséggel és bizonytalansággal szemben. Úgy vélem, a szerzőnek abban igaza van, hogy a munkásság jelentôs részénél valóban lázadásról volt szó: épp erre utal, hogy nemcsak a Fidesz, de a Jobbik is látványosan megerősödött. Nem a leendő hatalomhoz való „dör- 
gölőzés" kezdődött, hanem új, radikális megoldásokat hirdető politikai ágensek kereséséről, amelyek a baloldali-liberális koalíciós kormány politikájával szemben határozták meg magukat.

Ám a hazai tőkések esetében ez a szembenállás korántsem volt ilyen éles, így a váltás sem. Az ő esetükben nem annyira lázadásról vagy ideológiai azonosulásról, hanem sokkal inkább a 2010-re felemelkedő Fidesz által teremtett új politikai környezethez való rugalmas alkalmazkodásról volt szó. Azok a magyar tôkések, akik nem tudtak versenyezni a magasabb bért fizető, jobb munkakörülményeket teremtő, és még a szakszervezetek múködését is toleráló multinacionális cégekkel, politikai lojalitásukért cserébe a protekcionista nemzetállamnál kerestek menedéket. Ezt bizonyítja, hogy a Scheiring által „jobboldali tókéseknek” nevezett csoport tagjai a számukra rendelkezésre álló két jobboldali párt közül szinte kivétel nélkül a Fideszt választották, nem pedig a Jobbikot. A felemelkedő jobboldali erők közül csak a hatalomra kerülésre esélyes (majd hatalomra kerülő) párt felé fordultak, mert attól remélhettek szabályozási előnyöket és állami juttatásokat.

Habár az Egy demokrácia halála elsősorban kritikai politikai gazdaságtani elemzés, Scheiring Gábor bebizonyítja, hogy otthonosan mozog a politikai szociológia és a szúkebben vett politikatudomány nemzetközi szakirodalmában is. Végigelemzi a liberális demokrácia bukására vonatkozó domináns magyarázatokat, amelyek között a politikai elitek normaszegésére, a kulturális determinizmusra, a modernizáció kifulladására és a világrendszer hatásaira hivatkozó értelmezéseket emeli ki. A politikai voluntarizmusra összpontosító elitista magyarázatokat joggal érheti kritika mind a modernizáció-elmélet, mind pedig a világrendszer-elmélet képviselői részéről. Ám az egy országra vonatkozó, esettanulmányt igénylő kérdésekre a túl általános világrendszer-elméletnél az intézményelmélet vagy a politikai ágensek szerepét vizsgáló elitelmélet jobb válaszokat ad.

\section{AZ OSZTÁLY FOGALMA}

A könyv kulcskategóriái az osztály, az állam és a függőség fogalmai. Scheiring Gábor könyvének egyik újítása, hogy bátran rehabilitálja az osztályelemzést és hangsúlyozza, hogy az osztály fogalma a XXI. század buborék-társadalmaiban, az instabillá vált politikai környezetben és az individualizált tömegtársadalomban sem veszítette el létjogosultságát. Ragaszkodik hozzá, hogy a Marx által bevezetett fogalom - amelyet a huszadik század második felében többször elparentáltak - továbbra is aktuális, még ha nem is pontosan úgy, ahogy azt Marx elképzelte. A szerző a munkásosztályhoz tartozók körébe sorolja mindazokat, akik tudásukat vagy munkaerejüket adják el, ám egyúttal azt is leszögezi, hogy a mai társadalmakat már nem lehet pusztán két osztályra, a munkásokra és a tőkésekre tagolni. 
A munkásosztályon belül Scheiring különbséget tesz képzett és képzetlen munkások között, a tôkésosztályon belül pedig a transznacionális és a nemzeti tőke képviselői között. „Szúkebb értelemben” a munkásosztály fogalma alatt azokat érti, „,akik megélhetésük biztosítása érdekében kénytelenek saját munkaerejüket áruba bocsátani, és nem rendelkeznek jelentős mértékben sem gazdasági, sem kapcsolati, sem tudástőkével" (82. o.). Azzal azonban, hogy mit tekint tágabb értelemben vett munkásosztálynak, a szerző adós marad. Egy pillanatra úgy tưnik, mintha a technokráciát is ide sorolná, ám később leszögezi, hogy a menedzsereket és a szakértelmiséget a munkásságtól elkülönülő, új, kozmopolita technokrata osztálynak tekinti, amely végső soron közelebb áll a tőkésekhez, mint a munkásosztályhoz. Ezt követően a szerző az állam relatív autonómiájának tézisét is elfogadja, amiből azt a következtetést vonja le, hogy az államhatalom múködtetői önálló szereplőként alkotják a politikai osztályt.

Scheiring Gábor szerint a jelenkori globális kapitalizmusban tehát négy osztály létezik: a munkásosztály, a tőkésosztály, a technokrata tudásosztály és a politikai osztály. A munkaerő és a profittulajdon mellett osztályképző erővé válik a konvertálható tudás és az állami hatalom. A szerző által követett osztályelmélet tehát „nem feltételez szükségszerüen adott társadalmi osztályokat, a megélt osztályhelyzetekben a kulturális mező szimbólumainak és a politikai intézményeknek ugyanúgy szerepük van, mint az adott történelmi és földrajzi kontextusban létező gazdasági munkamegosztásnak, termelési módnak" (85. o.) Ráadásul nem kell, hogy az osztályok a mindennapok világában megnyilvánuljanak, elegendő, ha az eltérő érdekrendszerükből fakadó politikai cselekvéseik „bizonyos kritikai csomópontként múködő” válsághelyzetekben felszínre törnek.

Mindebből az rajzolódik ki, hogy a szerző meglehetősen laza osztályfogalommal dolgozik, amelyben a gazdasági struktúrák csupán az egyik lehetséges változót jelentik az osztállyá szerveződésben. Az osztályok alapvetően „magánvaló" osztályként (Marx), vagy „osztályhelyzetként" (Weber) léteznek, amelyek csak éles társadalmi konfliktusok idején dinamizálódnak és szerveződnek „magáért való” osztállyá (Marx), vagy társadalmi osztállyá (Weber). A szerző azonban még tovább bővíti az osztályelmélet érvényességi körét, amelylyel már Marx sem értene egyet - Bakunyin, Gyilasz, Szelényi és Gouldner viszont annál inkább. A szerző ugyanis azáltal, hogy a hagyományos antagonisztikus osztályok mellett az új, transznacionális, kozmopolita, szakértelmiségi technokrata osztályt is osztályként említi, elfogadja az „új osztály” elméletét. Végül a tudásosztály mellett Scheiring a politikai osztály fogalmát is bevonja az elemzésbe, amivel saját osztályelemzését olyan elméleti tradíciókkal tágítja ki, amelyek nemcsak a Gramsci és Poulantzas által képviselt marxi hagyományt, hanem mellettük Foucault és Bourdieu hatását is tükrözik.

A szerző tehát úgy igyekszik hű maradni az osztályelemzést rehabilitáló kutatási programjához, hogy az osztály fogalmát rendkívül tágan, a poszt- 
strukturalista megközelítésekre is nyitottan értelmezi. A struktúra és a cselekvő ágensek hatását együtt elemzi, továbbá osztályképző erőt tulajdonít olyan felépítményi tényezőknek, mint a politikai intézmény és a kulturális mező. Itt azonban a szerző már csúszós talajra érkezik, mert a "mező" és a "habitus" fogalmát Bourdieu éppen a struktúrákra és aktorokra tagolt osztályelemzés alternatívájaként dolgozta ki.

Scheiring osztályelemzése az immanens rendszerkritika keretei között mozog: kritikai pozíciója nem antikapitalista, hanem rendszeren belüli baloldali álláspontként fogalmazódik meg. Marx továbbra is fontos forrás marad számára, de nem annyira tartalmi, mint inkább módszertani szempontból. Elveti a proletariátus ideologikus, forradalmi ágensként való értelmezését, és a munkásság szociológiai megközelítésére koncentrál. Amikor például a kapitalizmus és demokrácia összeegyeztethetőségével foglalkozik, Adam Przeworskinak az 1980-as években írt munkáit gondolja tovább. Przeworski tézise szerint a tőkések és munkások között nincs mindig antagonisztikus ellentét, ellenkezőleg, képesek arra, hogy szembenálló érdekeik dacára tartós kompromisszumot kössenek egymással. A tókés uralom, a jogállam, a beágyazott pártrendszer és a kollektív érdekvédelem fogalmaival pedig a szociáldemokrata stratégia bontakozik ki a szemünk előtt.

Przeworski a szociáldemokrácia történetével foglalkozó kutatásaiban arra a következtetésre jutott, hogy a munkások számára a jóléti demokratikus kapitalizmus vonzóbb opció, mint a bizonytalan kimenetelú szocialista forradalom (Przeworski, 1985; Przeworski-Sprague, 1986). Amennyiben a kapitalista állam garantálni tudja számukra az anyagi jólét és a demokrácia lehetőségét, a munkások a kapitalizmust fogják választani a forradalommal szemben. A demokrácia osztálykompromisszum eredménye, amelyet gazdaságilag és politikailag jól szervezett osztályok képviselői kötnek meg. A második világháború utáni szociáldemokrata, kereszténydemokrata és szociálliberális rendszerek a jóléti államok által fenntartott demokratikus kapitalizmus modelljére épültek. Talán azért is alakulhatott ez így, mert a nyugati kapitalista demokráciákkal szemben egészen 1989-91-ig fennállt a Marxra hivatkozó, szovjet típusú rendszeralternatíva. Ez a rendszer ugyan nem volt se kulturálisan vonzó, se gazdaságilag sikeres, de katonailag sokáig komoly veszélyt jelentett az emberiség számára.

Scheiring Gábor könyvéből is kitûnik, hogy a klasszikus, osztálykompromisszumra épülő szociáldemokrata politika nem volt elérhető alternatíva a posztkommunista átalakulás sokkján átesett kelet-közép-európai országok számára. Az 1990-es években hatalomra kerülő új, demokratikus, posztkommunista elit a piaci koordináció elsődlegességében hitt, sőt voltak köztük olyanok, akik abszolutizálták a piaci logika társadalmi szerepét. A szerző őket nevezi piaci fundamentalistáknak. Ezekben az országokban a létező baloldal a modernizációs paradigma keretei között liberalizáló, piacosító és kulturálisan kozmopolita politikát folytatott, a létező jobboldal pedig a társadalmi alrend- 
szerek nemzetállami ellenőrzését pártfogolta. A baloldal egyszerre volt gazdasági és kulturális értelemben liberális, míg a jobboldal egyszerre volt mindkét értelemben antiliberális. Mindez megelőlegezte a demokratikus törésvonalakon túlmutató társadalmi polarizáció kialakulását. Scheiring elemzése meggyőzően mutat rá a magyar munkások és a gazdasági elit között egyre inkább elmélyülő materiális és kulturális szakadékra.

Az átalakuló kelet-európai társadalmak ezzel nem voltak teljesen egyedül, mert a 2008-as válság időszakára a nyugati országokban is megindult a demokráciát sokáig fenntartó osztálykompromisszum szétforgácsolódása. Ráadásul a vetélytárs nélkül maradó kapitalizmus maga is paradigmaváltáson esett át a hidegháborút követő évtizedekben. Az osztályelemzést megnehezítette, hogy a helyi jóléti kapitalizmusokat felváltó globális kapitalizmusban a jóléti állam helyébe a „piaci társadalom”, a demokrácia helyébe a „posztdemokrácia", a szervezett munkásosztály helyébe pedig a fragmentált, bizonytalan helyzetű prekariátus lépett (Crouch, 2004). A globális elit és a munkavállalói csoportok közötti megélhetési olló látványosan szétnyílt és az egyenlőtlenség kultúrája normalizálódott.

Scheiring az államszocialista osztálypolitika széthullását követő, kelet-európai vadkapitalista tapasztalatok ellenére - vagy tán épp azért - fontosnak tartja, hogy visszahozza a hazai társadalomtudományi diskurzusba az osztályelemzést. Ebben talán az a konstruktivista megközelítés is inspirálta, hogy azok a társadalmi jelenségek, amelyekre fogalmakat alkotunk, léteznek. A szerző „békeidőben” is munkásosztályról és tőkésosztályról beszél, amikor az osztálylyá szerveződés politikailag láthatatlan. Érdemes lett volna arra is kitérni, hogy mi a szerepe a rendszer fenntartásában a további két említett osztálynak: a technokrata és a politikai osztálynak. Ha elfogadjuk azt a plauzibilis állítást, mely szerint minden demokrácia osztálykompromisszum eredménye, akkor egy újabb kutatásban érdemes lesz megvizsgálni azt is, hogy e kompromisszumokat osztálytudatos szereplők, vagy hasonló osztályhelyzetben lévő, véletlenszerúen a hatalom közelébe sodródó cselekvők kötik-e meg. Hipotézisként megfogalmazható, hogy a felek osztálykompromisszumot kritikus történelmi pillanatokban - jellemzően válsághelyzetben - szoktak kötni, tehát akkor, amikor a hasonló osztályhelyzetbe tartozó szereplők osztálytudatát a válság átmenetileg dinamizálja.

\section{AZ ÁLLAM FOGALMA}

A kötet másik jelentős újítása az állam átalakulásának leírása. A rendszerváltás alatti és az azt követő időszakot egybevéve a szerző három szakaszt különít el egymástól és mindegyikhez az állam eltérő típusát rendeli. Az első az államszocializmusból megörökölt csökevényes jóléti állam, a második a húsz éven át tartó demokratikus időszakban kialakult versenyállam, a harmadik 
pedig az orbáni posztdemokratikus korszakban gyökeret eresztett felhalmozó állam. Scheiring szerint az államszocializmus korszaka nem a Kornai János által leírt „koraszülött jóléti államot” (Kornai, 1989; 1993) teremtette meg, hanem az ennél általa pozitívabban értékelt "csökevényes jóléti államot”. Tehát a szocializmus idején nem az volt a baj az állam jóléti szolgáltatásaival, hogy azok túl korán jöttek volna, hanem hogy túl kevés területre terjedtek ki. Itt vonzó intellektuális kihívás kínálkozott volna arra, hogy Scheiring részletesebben is kritikai elemzés alá vegye Kornai koncepcióját, de ezzel a lehetőséggel nem élt - nyilván azért, mert a könyvének elsődleges tárgya nem az 1989 előtti szocialista állam elemzése volt.

A rendszerváltás utáni korszakban a csökevényes jóléti államot fokozatosan a piacpárti (és helyenként neoliberális) „versenyállam” váltotta fel. A versenyállam (fogalmához lásd Drahokoupil, 2008) fő feladatának a piacosítást, a makroökonómiai stabilizációt, a vonzó befektetési környezet megteremtését, tehát a kapitalizmus sikeres adaptálását tekintette, és a versenyből kiesőket korai nyugdíjazással és munkanélküli segéllyel pacifikálta. Mindezzel lényegesen csökkent a foglalkoztatottak aránya a népességen belül, tehát a versenyállam, paradox módon, az eltartottak egyre nagyobb hányadát cipelte a hátán. Ez az ellentmondás megengedi azt a következtetést, hogy a versenyállam nem is volt igazán neoliberális, hiszen a verseny vesztesei számára a szociális béke fenntartása érdekében továbbmúködtette az államszocializmus egyes vívmányait. Itt talán érdemes lett volna jobban kiemelni a rendszerváltást közvetlenül követő évek gazdasági és politikai elitjének felelősségét a privatizáció nemcsak antiszociális, hanem kriminális - „menedzselése” miatt. A kialakuló versenyállam domináns volt, de nem kizárólagos, mert a korszak egészében fennmaradtak a csökevényes jóléti állam egyes struktúrái, amelyek a kapitalizmusba való átalakulás társadalmi feszültségeit csökkentették. Például ezekre a struktúrákra és elvárásokra kívánt építeni a Medgyessy-kormány, amikor 2002-ben meghirdette a „jóléti rendszerváltás” szociáldemokrata programját.

A rendszerváltást követő második évtized végére azonban kiderült, hogy a versenyállam nem tudta tovább erősíteni az ország versenyképességét. Ami az 1995-2005 közötti évtizedben még sikeres volt, az az ezt követő években fokozatosan csődött mondott. A 2008-as világgazdasági válság kézzelfoghatóvá tette a gazdaságpolitika megváltoztatásának szükségességét. A versenyállam elitje azonban a válságra a régi módon reagált: továbbra is pénzügyi és gazdasági megszorításokban gondolkodott. Mindez gyors politikai hitelvesztéshez és a politikai kereslet radikális megváltozásához vezetett.

A 2010 után kialakult államot Scheiring a Magyarországon kevésbé használt, de a nemzetközi szakirodalomban ismert „felhalmozó állam” fogalmával (lásd Wolfe, 1977) írja le. Ebben a paradigmában az állam feladata egyes hazai tôkéscsoportok erőteljes és túlzott jutalmazása révén belső erőből, hazai erőforrásokra támaszkodva felpörgetni a gazdasági fejlődést. Ám kérdés, hogy a 
felhalmozó állam fogalma mennyiben alkalmazható arra a helyzetre, amikor az államot belülról elfoglaló politikai vállalkozók a jogállami kondíciókat lerombolva a közpénzeket az általuk felépített strómanokhoz, és a politikai lojalitás alapján hozzájuk kötődő tőkésekhez csoportosítják át. Ez az állam keveseket elhalmoz, de sokakat kifoszt: egy viszonylag szúk kört szisztematikusan megjutalmaz - ha ugyan az államnak egyáltalán "relatív autonómiája” van, tehát egyáltalán leválasztható erről a körről - míg a leszakadó rétegekkel szemben „munka alapú", szociáldarwinista politikát követ. Fennmaradását nem csupán a 2010-es évek világgazdasági konjunktúrája tette lehetővé, hanem a közmédia állami kontrollja, a társadalom megosztása, az idegenellenes, etnicista politika, a permanens háborús retorika, a kormányfő személyes karizmája, valamint az Európai Unió bizonytalan - strukturálisan korlátozó, de esetileg támogató - politikája is (Bozóki-Hegedűs, 2018b; Tamás Gáspár Miklós, 2020).

Scheiring korrekt módon megemlíti a saját álláspontjával ellentétes megközelítéseket is - Kornai János elméletén túl például Magyar Bálint „maffiaállam" (Magyar, 2015; 2018) koncepcióját - de érdemben nem száll velük vitába. Utóbbit neoutilitárius megközelítésnek nevezi. Egy ponton félreérti a maffiaállam tézisét, amikor azt a "haveri kapitalizmus” körében tárgyalja. A haveri kapitalizmusban ugyanis az egymásnak kölcsönösen osztogató „haverok" többé-kevésbé egyenlők. A maffiaállam lényege viszont a központosított, vertikális, személyes hatalom. Gyakorlóinak köre nem annyira a reciprocitással és horizontális kapcsolatokkal írható le, mint inkább a "fogadott politikai család" viszonyrendszerével, amelyet egyetlen személy, a gazdasági és politikai hatalmat, befolyást és presztízst felülről osztogató, „családfö", mint politikai boss irányít, akit követői kritikátlanul elfogadnak. Ellentétben a haveri kapitalizmussal, a maffiaállamban minden pozícióban lévő személy a „családfó" által lekenyerezett szereplő.

A posztkommunista maffiaállam perszonalizált rendszer, amely nem a fennálló formális intézményekre, hanem a vezető informális hatalmára és ebből fakadó önkényes döntéseire épül. Ebből fakadóan mindegy, hogy az államfö, a legfőbb ügyész, az alapvető jogok biztosa, az alkotmánybíróság vagy a médiatanács tagja papíron „független” szereplő, mert őket a gyakorlatban a rezsim névadója irányítja. Ebben a struktúrában a központi döntések a tulajdonviszonyok átrendezésére is irányulhatnak, például tranzitállamosítás módszere szerint. Az állam „ragadozó" természete a vezér azon törekvésére épül, hogy klienseinek igényei ki legyenek elégítve, mert támogatásuk nélkül a rendszer nem tartható fenn. Mindazonáltal a maffiaállam tézise részleges elmélet, mert az állam múködésére koncentrál és önmagában nem ad választ az állam és a társadalom viszonyára és nem elemzi a rendszer legitimációját vagy a társadalom belső mozgásait sem. Ez utóbbira inkább az útfüggőségre (path-dependency) építő elméletek - a refeudalizációra, a kultúrára és az értékrendszerre vonatkozó kutatások - hívhatók segítségül. 
Az Orbán-rezsimben államosítás és újraprivatizálás egyaránt megfigyelhető, de mindez végső soron nem is lényeges, mert elmosódnak a határok a magántulajdon és a köztulajdon, valamint az állam, a párt és a vezető köre között. Utóbbiak közös halmazát nevezhetjük „politikai családnak”. A felhalmozó állam fogalma azért lehet problematikus, mert a kormányfő az ország vagyonát lényegében a sajátjaként kezeli, amitől a rendszer szultanisztikus (más megközelítésben: neopatrimoniális, neoprebendális) vonásokat ölt (Csillag-Szelényi, 2015). Az állami felhalmozás kizsákmányoló jellegú, mert elszívja az erőforrásokat a kisebb keresetűek elől, és a közcélokat is aszerint állapítja meg, hogy e források átcsoportosíthatók-e a felhalmozó klikk számára.

A szerző a felhalmozó állam két korszakát különbözteti meg. Az első szakasz a XVIII. század végére, a XIX. század elejére esik, amikor a nemesség és a burzsoázia közötti kiegyezés alapján a régi rend megtarthatta befolyását, cserében az általa irányított állam a burzsoázia tôkefelhalmozását szolgálta. Ez a „demokrácia előtti” állam nem volt érdekelt a munkásosztály rendszerbe integrálásában - sőt, kifejezetten annak kirekesztésére törekedett - mert elsődleges céljának azt tekintette, hogy állami beavatkozással hazai és nemzetközi piacokat szerezzen a burzsoázia számára. Scheiring e ponton az amerikai vadnyugati vasútépítő nagyvállalatokat (Central Pacific Railroad, Union Pacific Railroad), valamint a brit parlamenthez kötődő Kelet-indiai Társaság nevét említi a felhalmozó állam kedvezményezettjeinek klasszikus amerikai és angol példáiként. A szerző szerint - legalábbis az angol esetben - volt két, egymástól független szereplő: a felemelkedőben lévő burzsoázia és a régi, arisztokratikus rend, amelyek kompromisszumot kötöttek egymással és közös, nagy projektekbe vágtak bele.

A felhalmozó állam másik korszaka (egyúttal típusa) a szerző szerint a félperifériás magyar gazdaságban figyelhetó meg, ahol a posztkommunista felhalmozó állam nem csupán közvetít a hazai és a nemzetközi tőke között, hanem mindkettejük érdekét kiszolgálja. Scheiring szerint a versenyállam csak a kapitalizmus bevezetésére és múködtetésére törekedett, és ezáltal a transznacionális tőke befolyása alá került. Vele szemben a felhalmozó állam - szintén a munkásosztály marginalizálása révén - szövetségest talált a nemzeti tőkében a transznacionális tőkével szemben, és előbbi érdekeit próbálja ellensúlyként képviselni az utóbbi ellenében. Erre azért nyílik lehetősége, mert az állam, mint politikai osztály egyúttal saját osztályérdekeit képviseli és egyaránt törekszik a politikai ellenzék és az alávetettek kirekesztésére. Míg tehát a versenyállam a demokrácia keretei között is tudott érvényesülni, a felhalmozó állam rákényszerül a demokráciával való szakításra, mert különben nem maradhatna fenn.

A felhalmozó állam tehát nem fér össze a demokráciával. Míg azonban a centrumországok korai felhalmozó állama két osztály kompromisszuma volt, a félperifériás posztkommunista régió magyar felhalmozó állama hármas szö- 
vetségként (politikai osztály, transznacionális tőke, nemzeti tőke) van leírva. Ez azonban már jobban hasonlít a dél-amerikai új függőségi elméletek által leírt modellre, mint a régi angliai vagy észak-amerikai fejlesztési stratégiákra. A mai félperifériás autoriter rendszerben a politikai osztály azáltal hozza helyzetbe a nemzeti tőkéseket, hogy maga alá rendeli és feltétlen politikai lojalitást vár el tőlük. Ahogy a szerző írja: „a hatalmi tömb az intézményi autoritarizmust és az autoriter populizmust kombináló tekintélyelvư hatalomgyakorlást folytat az új felhalmozási rezsim stabilizálása érdekében" (257. o.) Cégek és vezetőik kerülhetnek rövid időn belül a csúcsra, majd tûnhetnek el a süllyesztőben az állam akaratából. Az Orbán-rendszerben nem a nemzeti tőkésosztály és a politikai osztály egymástól független szereplőként megkötött kompromisszumáról van szó, hanem a tőkésosztály politikai behódolásáról. Olyan kapitalizmus ez, amelyben a tôkések sorsa rendszerszintűen a politikai lojalitásuktól függ.

Ennélfogva e két, időben távol eső „ffelhalmozó állam” közös nevezőre hozása túlságosan is kalandos vállalkozásnak tûnik. Abból, hogy az elmúlt évszázadok történetéből releváns példákat tudunk mondani arra, hogy a felhalmozó állam erőteljesen hozzájárult egyes kapitalista vállalatok felvirágzásához, nem következik, hogy ezekben az országokban az állami beavatkozás rendszerszintû́ volt. Nagy képzelőerőre van szükség ahhoz, hogy a James Lancaster által létrehozott és a londoni politikai körök által támogatott Kelet-Indiai Társaságot, valamint Mészáros Lőrinc magyar vállalatbirodalmát ugyanabban a paradigmában, egymással analóg példaként szemléljük. Míg az előbbi az Indiai-óceánon és a Bengáli-öbölben, globális nemzetközi versenyben állt helyt évszázadokon át, addig az utóbbi alig tízéves vállalatvezetői múltra visszatekintő hazai szereplő legfeljebb a Balkán néhány kisállama felé nyújtózkodik. A két vállalatbirodalom - minden, itt nem részletezendő különbsége ellenére - abban kétségkívül hasonlít, hogy egyaránt ellátott politikai és gazdasági funkciókat. Míg azonban a Kelet-Indiai Társaság csak politikai kérdésekben tartozott a brit korona fennhatósága alá, de gazdasági tevékenységében szabad volt, addig Mészáros Lőrinc vállalatcsoportjánál a politikai és a gazdasági lojalitás szálai elválaszthatatlanok egymástól.

Rendkívül izgalmas lenne, ha Scheiring a felhalmozó államra nemcsak ennyire extrém módon eltérő példákat hozna - amelyek viszonylag könnyen megkérdőjelezhetôk - hanem a magyar állam közelebbi szomszédait is elemezné. Kíváncsi lennék, hogy a szerző a szlovák Meciar korrupt rendszerének titkosszolgálati és rendőrállamát, a szerb Milosevic paramilitáris, gengszterkapitalista államát, vagy akár a mai lengyel autoriter állam múködését is a "felhalmozó állam” fogalmi körében tárgyalná-e. A könyv elemzéséből nem teljesen világos, hogy a szerző mennyiben tartja egyedinek a magyar felhalmozó államot régiós összehasonlításban, ahol az egyes országok 1990-ben hasonló „starthelyzetből” vágtak bele a piacgazdaság kiépítésébe. 
A felhalmozó állam fogalmának magyarországi alkalmazásával tehát nem az a probléma, hogy az "túl barátságos" lenne az Orbán-rendszerrel, hanem a conceptual stretching, a fogalom érvényességi körének túlzott kiterjesztése az elemzés során. Kétszáz éves összehasonlításban az osztályok jellege, száma és tevékenységük valódi tartalma már nem feleltethető meg egymásnak olyan kézenfekvő módon, ahogy a szerző feltételezi, így a probléma módszertani jellegû.

\section{A FÜGGÖSÉGI ELMÉLETEK}

A könyv harmadik sarokpontja a függőségi elmélet. A szerző ezt az elméletet a modernizációs elmélettel szemben határozza meg, helyesen, hiszen a függőségi elmélet épp a annak egyoldalúságaira adott válaszként született meg. Az a megközelítés viszont túlfeszítettnek tûnik, hogy a modernizáció gondolatát liberálisnak nevezi. Annyiban volt liberális, amennyiben a második világháború utáni korszakot liberálisnak tekintjük. A modernizációs teória a XX. század ötvenes-hatvanas-hetvenes éveiben, a két világrendszer versengése és békés egymás mellett élése idején nem egyszerúen liberális elmélet volt, hanem olyan fejlődéselméleti paradigma, amelyet Hruscsovtól Huntingtonig számos eltérő eszmei irányultságú politikai szereplő és politikatudós elfogadott. A modernizációs elmélet fő tanait sokáig egyaránt osztották liberálisok, konzervatívok, szocialisták, sőt a feltörekvő országok nacionalistái is. A hetvenes évek éles kritikái nyomán rákényszerült a megújulásra, és a nyolcvanas évektől újabb hullámokban jelentkezett. A régi modernizációs elméletekkel szembeni jogos kritika (túl absztrakt megközelítés, alternatív utak elvetése, egyenes vonalú fejlődés feltételezése, a nyugati fejlődési pálya abszolutizálása, a nemzetállami kerethez, mint elemzési egységhez való ragaszkodás stb.) már nem volt érvényes az új modernizációs elméletekre.

Mindez a megújulás éppúgy jellemző volt a függőségi elméletekre. Az André Gunder Frank nevéhez kötődő régi függőségi elmélet a dependenciát hagyományos gazdaságpolitikával megváltoztathatatlan történelmi determinációnak tekintette, és olyan fejlődési stratégiát próbált kidolgozni, amely gyökeresen szakít a függőséggel (Frank, 1966). Az 1970-es évek közepétől jelentkező új függőségi elméletek képviselői ezzel szemben ráébredtek arra, hogy a világgazdasági függőség olyan adottság, amelyen a forradalmi út nem javít, hanem inkább csak ront. Viszont a függő fejlődés nemcsak hátrányokat hozhat, hanem, jó fejlesztési stratégiával, előnyöket is felcsillanthat. Scheiring Gábor e könyvében néhol hajlik arra, hogy az új függőségi elméleteket a régi modernizációs elméletekkel állítsa szembe. Az új függőségi elméletek a régi modernizációs elméleteknél jóval szofisztikáltabbak, de az újakkal összehasonlítva ez már nem mondható el róluk. A szerző pozíciója tehát rendszerkritikus, de nem rendszerellenes: nem a függést eleve csapdának tartó, Frank-fé- 
le forradalmi, régi függőségi elméletekre támaszkodik, hanem - Cardoso, Faletto és Peter Evans nyomán - a függőséget a fejlődés új modelljének esélyeként értelmező elemzésekre (Cardoso-Faletto, 1979; Evans, 1979). Utóbbiakból pedig már nem a szocialista forradalom igénye következik, hanem baloldali szociáldemokrata program kidolgozása a kapitalizmus keretei között.

A latin-amerikai példák sokszor megvilágító erejúek a 2010 utáni magyar rendszerrel kapcsolatban is, különösen nemzetközi beágyazottságának megértésében. Ilyen példa lehet a bürokratikus autoriter állam (bureaucratic authoritarianism, vagy röviden: $\mathrm{BA}$ ) Guillermo O'Donnell által kidolgozott fogalma, amelyet az 1970-es évek argentin diktatúrája gazdaságpolitikájának leírásához használt (O’Donnell, 1988). A BA-állam jellegzetessége ugyanis abban állt, hogy a gazdaság versenyképessé tétele érdekében tudatosan korlátozta a demokráciát és a munkások jogait, és arra törekedett, hogy politikailag marginalizálja a bérből és fizetésből élőket. Ezt a megközelítést a szerző nem elemzi, pedig nagyon hasonló ahhoz, amit a magyar felhalmozó állam múködésérôl leír: „Ha nem a felhalmozás lenne a hatalmi kompromisszum lényege, akkor nem lenne szükség a felhalmozás veszteseinek politikai semlegesítésére, azaz ellenvéleményük megszervezésének politikai megakadályozására" (255. o.). A semlegesen csengő „felhalmozás” kifejezés valójában nagyon is agresszív beavatkozás, ami a javak átcsoportosítását jelenti, beleértve a tulajdonviszonyok önkényes átrendezését.

Az új függőségi elméletek a gazdasági fejlődést a multinacionális tôke, a nemzeti burzsoázia és az állami bürokrácia háromszögében vizsgálják, és a három szereplő között létrejövő koalíciók lehetséges konfigurációinak hatásait elemzik. A Peter Evans által leírt hatalmi háromszög a transznacionális tőke, a helyi tőke és az „állami burzsoázia” (vagyis az államapparátus „vállalkozó frakciója”) összjátékára, változó viszonyaira épül (Evans, 1979; 1989). Ennek következtében, a hatalmi ciklusok váltakozása szerint, a domináns politika lehet populista vagy neoliberális, de a rendszernek nem feltétele, hogy egyetlen személyhez kötődjön. Az Orbán-rezsim a latin-amerikai országok közül a perszonalizált uralmi rendszerekre hasonlít, de a többiektől különbözik.

Olykor úgy tûnik, mintha a szerzőnek a magyar eset elemzésén túlmutató célja a liberális világrend átfogó kritikája lenne. Ezt jelzi, hogy jóval kritikusabb a modernizációs elmélet híveivel szemben, mint annak tagadásaként létrejött függőségi vagy világrendszer-elméletek képviselőivel. Holott a világrendszer-elmélet módszertanilag nehezen (vagy egyáltalán nem) alkalmazható az egyetlen országban végbement rapid változások magyarázatára, mert képviselői azt is a világrendszer mozgásával magyarázzák. Ezáltal ok és okozat felcserélhetővé válik - a világrendszerben bekövetkezett elmozdulás egyszerre lehet oka és következménye a jelenség magyarázatának - így az elméleti következtetések rendre tautologikusak maradnak (vö. Wilkin, 2016). Amint azt a szerző is látja, arra a kérdésre, hogy miért éppen Magyarországon omlott 
össze a demokrácia - és miért nem Szlovéniában, Romániában vagy Szlovákiában - a világrendszer-elmélet nem tud jó magyarázatot adni, hiszen nagy elemzési egységekben és hosszabb történelmi távlatokban mozog.

A nemzetközi gazdasági és politikai függőségek elemzésénél ez a veszély nem áll fenn, ellenkezőleg, rendkívül szerteágazó és esetről esetre változó kapcsolati hálókat lehet felfejteni a kutatások során. Például azt, hogyan próbálja tágítani nemzetközi mozgásterét az európai félperiférán elhelyezkedő posztdemokratikus ország vezetője és miként használja fel az ország EU-tagságát - haszonelvúen, bargaining chip-nek tekintve - mind a hazai, mind a balkáni, mind pedig a "keleti nyitással” összefüggő politikájában. A függőségi elmélet hatalmas utat tett meg az elmúlt ötven évben, mialatt periférikus, a Harmadik Világra koncentráló, forradalmi marxista elméletből a globalizáció, a multipoláris világrend, és a kölcsönös függés hálózatainak kialakulása révén domináns fejlődéselméleti paradigmává vált.

\section{AZ EMPIRIKUS ELEMZÉS}

Scheiring Gábor könyvének kiemelkedő erénye a problémaérzékenység, az interdiszciplináris közelítés és a módszertani pluralizmus, amelyek eredményeként a szerző nemcsak elméleti, hanem empirikus következtetésekre jut. Munkájában nemcsak teoretikus politikai gazdaságtani, hanem a rendszer múködését leíró empirikus szociológiai kutatásokat is végez. Habár e recenzióban elsősorban a könyv elméleti alapjaival foglalkoztam, nem hagyhatom említés nélkül azt az eleganciát, ahogyan a szerző az elméleti kérdésfeltevéseit az empirikus kutatásban alkalmazza. Ez azért fontos, mert egyértelmúvé teszi, hogy a tudományos megismerésben az elméletalkotást és a valóság feltárását egyaránt fontosnak tartja. Tudja, hogy a valóság nem túnhet el az elmélet szivárványos világában, mert - ahogyan Vörösmarty A merengőhöz címú versében írja - „a látni vágyó napba nem tekint”. Ennek szellemében Scheiring nagy figyelmet fordít az empirikus fejezetekre is, amelyek egyaránt foglalkoznak a gazdasági elittel, a munkásosztállyal, illetve a felhalmozó állam gyakorlati múködésével és a kötet fő mondanivalójához kapcsolódó egyéb résztémákkal.

A forgóajtó-metaforát használva a szerző bemutatja a gazdasági elit képviselőinek életpályáját. Ezek közös jellegzetessége, hogy a rendszerváltást követő évtizedekben az elitbe tartozók rendre megfordultak az államigazgatás vezérlőpultjai mögött is. A szerző arra keres választ, hogy honnan jöttek, hol végeztek, merre dolgoztak, és hogyan váltogatták munkahelyeiket ezek a szereplők az állami és a magánszektor között, illetve mennyiben mozogtak a nemzeti és a nemzetközi tőke világában. A kutatás feltárta, hogy míg a „baloldali" pénzügyminiszterek inkább a bankszektorból érkeztek, addig a ,jjobb- 
oldaliak" kevésbé a gyakorlati életből, mint inkább az egyetemi szférából. Mindkét irányzatban megtalálhatók a piacosítás radikális hívei és a mérsékeltebb modernizátorok, ezért a gazdaságpolitikában az absztrakt ideológiai irányultságnak kevesebb értelme van. Ezeket a történeteket e könyvben inkább vázlatosan - főként az ismert nevekre koncentrálva -, nem szisztematikusan tekinti át, de a feltárt összefüggések így is revelációként hatnak. Ebben a formában a kutatás első eredményei azt a gramsciánus szellemben fogant további kutatási hipotézist sugallják, hogy a gazdasági vezetők beállítódásai és döntései az életútjukból megmagyarázhatók. Ez a fejezet önálló esettanulmányként is olvasható, de épp ezért érdemes lenne később önálló könyvben részletesen is kidolgozni.

Scheiring azonban nem csak az elittel foglalkozik. A tőkések különböző csoportjainak pozicionális - a politikai főhhatalomhoz való közelségét is bemutató - elemzése mellett kiterjedt figyelmet fordít a munkásság képviselőinek megszólaltatására. Az egykori bányászvárosok munkásaival készített interjúk bepillantást engednek a munkásosztály szegényebb csoportjainak drámaian megváltozott helyzetébe. A helyenként megrázó vallomásokból vett idézetek azt húzzák alá, hogy a munkások - érthető módon - visszasírják a Kádár-rendszert, amelyben fiatalon, erejük teljében, olyan közösségekben dolgozhattak, amelyekben erős volt a kollektív szellem és az egyenlőség ethosza. Az erős családi és szomszédi kapcsolatok és a szocialista brigádok belső szolidaritása akkor is pozitív példa maradt számukra, ha életük tágabb, távolabbi kereteit a politikai elnyomás határozta meg. A munkások közötti durkheimi „mechanikus szolidaritás" (Durkheim, 1984) azonban azért is lehetett ennyire erős, mert védekező jellegû́ volt (Ágh, 1987). A társadalmi önvédelem mikroszintû szolidaritás-közösségei voltak hivatva kivédeni a makroszintű bizalmatlanságot, vagyis a demokráciákból ismert „organikus szolidaritás” teljes hiányát. Senkiben se bízhattak, csak egymásban.

Az empirikus fejezetek igazi érdeme, hogy közel hozzák az olvasóhoz a könyv fó állításait, amelyet a szerző kvantitatív módszerekkel, statisztikailag is alátámaszt. Erre annál is inkább szükség van, mert az interjúk maguk is szükségképpen példálózó jellegüek, s egyszerre szolgálnak a történet bizonyítására és illusztrálására. Az olvasóban némi hiányérzet támadhat az interjúk olvastán, mert belőlük csak az 1989 utáni új rendszer egyértelmú elutasítása hallatszik ki, disszidens hangok nem jelennek meg. A megkérdezettek a vesztesek nézőpontjából értékelik a rendszerváltás után kialakult új gazdasági helyzetet. A szerző által bemutatott kutatás hajlik arra, hogy a Kádár-rendszer - elképzelt fennmaradása esetén - jobb lett volna a bérből és fizetésből élőknek, jobb perspektívát ígért volna gyermekeik számára, mint a rendszer bukása után megszületett új demokrácia. A szerző személyes életútja - amelyet az előszóban röviden megoszt olvasóival - azonban azt mutatja, hogy a rendszerváltás hihetetlen kitörési lehetőségeket is nyújtott a tehetséges, nem értel- 
miségi családból származó fiatalok számára. A Kádár-korszakról ambivalens képet őriz az utókor, amelyben a rendszer szinte egyszerre jelenik meg „munkásparadicsomként” és a "munkásáruló” káderbürokrácia uralmaként. Az interjúkból azonban az első interpretáció domborodik ki.

A 2010 után megszilárdult rendszer retorikája azt sugallja, hogy a „"neoliberális uralom" korszaka után a kormány megvédi a magyar embereket: a nemzeti burzsoázia szövetséget kötött az állami bürokráciával a multik ellen, hogy megvédje a hazai munkavállalókat a kizsákmányolástól. A populizmus azonban csupán elfedni hivatott azt, ami az Orbán-rendszert a demokratikus korszakkal összeköti. Valójában az orbáni felhalmozó állam - ezúttal „stratégiai megállapodások" és egyes kulcsfontosságú szektorok favorizálása révén - továbbra is a külföldi tôkebevonást támogatja. Talán nem véletlenül, hiszen a magyar munkások a multiknál jobb munkakörülmények között dolgoznak, magasabb bért vihetnek haza, továbbá a multikkal sport- és infrastrukturális támogatásokban is meg lehet egyezni, ami hozzájárul a rendszer legitimitásához. "Ne figyeljenek oda arra, amit mondok, egyetlen dologra figyeljenek, amit csinálok" - adta meg a kulcsot leendő rendszere értelmezéséhez még hatalomra kerülése előtt a névadó (Orbán, 2011).

Míg az Orbán-rendszer a saját klientúráját, a felső-középosztályt, az egyházakat és a látványsportokat támogatja, az ehhez szükséges állami bevételek jelentős részét az itt megtelepedett autógyárak és multinacionális cégek termelik meg. További részét a rezsim az európai adófizetôktől kapja EU-támogatások formájában, egy kisebb porcióját pedig a külföldön dolgozó magyarok utalják haza. A magyar munkásosztály jelentős része kékgalléros vállalkozóként, bébiszitterként vagy szociális gondozóként, nyugat-európai országokban dolgozik. A munkásosztály - ha e vitatott kifejezést érvényesnek fogadjuk el - 2010 óta a lábával is szavaz: az „exit” és a „loyalty” között választhat, mert hatékony tiltakozásra nincs lehetősége (vö. Hirschman, 1970).

Végül, mielőtt az olvasó a munkásságot kezdené hibáztatni a magyar demokrácia haláláért, a szerző hangsúlyozza, hogy a munkásosztály lázadása nem adott felhatalmazást a Fidesznek a demokrácia lebontására. A munkások nem valami ellen, hanem valamiért lázadtak: nem a demokrácia ellen, hanem a beígért nagyobb biztonságért. A szerző szerint lehet, hogy a munkások antiliberálisak voltak, de nem voltak antidemokraták. Ennek az állításnak az érvényességét azonban épp a szerző által készített munkásinterjúk kérdőjelezik meg, mert a megkérdezettek rendre jobbnak tartották a kádári diktatúrát, mint az utána következő demokráciát. Miért ne adhattak volna a Fidesznek felhatalmazást a demokrácia lebontására az egzisztenciális biztonságot jelentő új munkalehetőségek reményében?

Talán azért, mert mást értettek a demokrácia fogalma alatt. Demokrácia alatt a saját szúkebb családi-szakmai, kollegiális szolidaritás-közösségeiket értették és nem érdekelték őket a nagy struktúrák, a tágabb horizont, a rend- 
szer maga. Úgy látták, hogy 1989 után széthullottak ezek a közösségek. Az optimista várakozásokkal szemben a munkások a kapitalista demokrácia kialakulását nem pozitív civilizációs (vö. Sztompka, 1995), hanem dehumanizációs fordulatként élték meg. A demokrácia fogalmát egyrészt visszavetítették a múltba, az egykor létezett helyi szolidaritás-közösségekre, másrészt egyre nagyobb várakozással fordultak az etnikai identitás elsődlegességét sulykoló politikai erők felé. A demokráciát nem állampolgárként, hanem kisemmizett munkavállalóként keresve, joggal vélhették úgy, hogy a politika felhőrégióiban történő események az ő mikrovilágukat tovább már nem ronthatják; a demokratikus rendszer országos szintű megőrzése nem az ő dolguk, így a lázadásukban nincs vesztenivalójuk.

Scheiring könyvét a szakirodalom átfogó ismerete, igényes elemzés és módszertani pluralizmus jellemzi. Munkájában egyaránt alkalmazza a kvantitatív és kvalitatív megközelítéseket, és sikerrel törekszik az elmélet és az empíria egyensúlyban tartására. Szokatlan könyv Scheiring Gáboré: olvasás közben szinte minden lényeges állításával vitára ingerel, de a végén mégiscsak oda jutunk, hogy az összképet tekintve igaza van.

\section{IRODALOM}

Ágh Attila (1987): A védekező társadalom. Magyar Tudomány, 1.

Block, Fred (n. d.): „Reframing the Battle: Market Fundamentalism vs Moral Economy”. Longview Institute.

Bozóki, András-Hegedús, Dániel (2018a): Democracy, Dictatorship and Hybrid Regimes: Concepts and Approaches. In: Magdalena Solska-Florian Bieber-Dane Taleski (eds.): Illiberal and Authoritarian Tendencies in Central, Southeastern and Eastern Europe. Bern, Peter Lang, 21-49.

Bozóki, András-Hegedús, Dániel (2018b): An Externally Constrained Hybrid Regime: Hungary in the European Union. Democratization, April 13. https://doi.org/10.1080/13510347.2018. 1455664.

Cardoso, Fernando H.-Faletto, Enzo (1979): Dependency and Development in Latin America. Berkeley, University of California Press.

Crouch, Colin (2004): Post-Democracy. Cambridge, Polity Press.

Csillag, Tamás-Szelényi, Iván (2015): Drifting from Liberal Democracy: Traditionalist / Neoconservative Ideology of Managed Illiberal Democratic Capitalism in Post-Communist Europe. Intersections, 1. 18-48.

Drahokoupil, Jan (2008): The Rise of the Competition State in the Visegrád Four: Internationalization of the State as a Local Project. In: Bastiaan Van Apeldoorn et al. (eds.): From Lisbon to Lisbon: Contradictions and Limits of Neoliberal European Governments. London, Palgrave, 187-208.

Durkheim, Émile (1984): The Division of Labor in Society. New York. The Free Press.

Evans, Peter (1979): Dependent Development: The Alliance of Multinational, State and Local Capital in Brazil. Princeton, Princeton University Press. 
Evans, Peter (1989): Predatory, developmental and other apparatuses. Sociological Forum, Vol. 4, No. 4, 561-587.

Frank, André Gunder (1966): The Development of Underdevelopment. New York, Monthly Review Press.

Hirschman, Albert O. (1970): Exit, Voice, Loyalty. Cambridge, Harvard University Press.

Kornai János (1989): Indulatos röpirat. Budapest, HVG Rt.

Kornai János (1993): A szocialista rendszer. Kritikai politikai gazdaságtan. Budapest, HVG Rt.

Kovács, János Mátyás-Trencsényi, Balázs (2020): Brave New Hungary: Mapping the System of National Cooperation. Lanham-Boulder, Lexington Books.

Levitsky, Steven-Way, Lucan A. (2010): Competitive Authoritarianism: Hybrid Regimes After the Cold War. Cambridge, Cambridge University Press.

Magyar Bálint (2015): A magyar maffiaállam anatómiája. Budapest, Noran Libro.

Magyar, Bálint (2018): Towards a Terminology for Post-Communist Regimes. In: Bálint Magyar (ed.): Stubborn Structures: Reconceptualizing Post-Communist Regimes. Budapest-New York, CEU Press, 97-176.

Magyar, Bálint-Vásárhelyi, Júlia (eds.) (2017): Twenty-Five Sides of a Post-Communist Mafia State. Budapest-New York, CEU Press.

O’Donnell, Guillermo (1988): Bureaucratic Authoritarianism: Argentina 1966-1973 in Comparative Perspective. Berkeley, University of California Press.

Orbán Viktor (2011): Orbán a Wikileaksen: Ne arra figyeljenek, amit mondok, hanem arra, amit teszek. Paraméter, szeptember 6.

Przeworski, Adam (1985): Capitalism and Social Democracy. Cambridge, Cambridge University Press.

Przeworski, Adam-Sprague, John (1986): Paper Stones: A History of Electoral Socialism. Chicago, University of Chicago Press.

Schedler, Andreas (ed.) (2005): Electoral Authoritarianism: The Dynamics of Unfree Competition. Boulder, Lynne Rienner; Andreas Schedler (2015): The Politics of Uncertainty: Sustaining and Subverting Electoral Authoritarianism. Oxford, Oxford University Press.

Scheiring Gábor-Szombati Kristóf (2019): Ezért nem rengették meg a rabszolgatörvény-ellenes tüntetések az Orbán-rezsimet: A baloldali politika strukturális csapdája. Mérce, december 26.

Scheppele, Kim Lane (2020): Orbán's Emergency. Hungarian Spectrum, March 22.

Soros, George (1998): The Crisis of Global Capitalism. New York, Public Affairs. Magyarul (1999): A globális kapitalizmus válsága. Budapest, Scolar.

Szalai Erzsébet (2004): Tulajdonviszonyok, társadalomszerkezet és munkásság. Kritika, 33: 9, 2-6. Sztompka, Piotr (1995): Cultural and Civilizational Change: The Core of Post-Communist Transition.

In: Bruno Grancelli (ed.): Social Change and Modsernization: Lessons from Eastern Europe. Berlin-New York, De Gruyter, 235-248.

Tamás Gáspár Miklós (2020): Szabadság és járvány. Mérce, április 12.

Wilkin, Peter (2016): Hungary's Crisis of Democracy: The Road to Serfdom. New York, Lexington Books.

Wolfe, Alan (1977): The Limits of Legitimacy: Political Contradictions of Contemporary Capitalism. New York, The Free Press. 